\title{
MURAL KAMPUNG BANTARAN KALI BORO: PEMBERDAYAAN KAMPUNG MELALUI KEGIATAN KESENIAN
}

\author{
Endang Sri Handayani ${ }^{1}$, Figur Rahman Fuad ${ }^{2}$ \\ Pendidikan Seni Rupa FKIP Universitas Sebelas Maret ${ }^{1}$ \\ Pendidikan Seni Rupa FKIP Universitas Sebelas Maret ${ }^{2}$ \\ Endangsri71@staff.uns.ac.id ${ }^{1}$
}

\begin{abstract}
Kampung as the important factor the culture of a city plays important role in teh city develpoment. The community movements in managing their environment has become an interesting thing to discuss. This reserach is a qualitative study on the comunity creativity residing in Kali Boro riverside. It exproses the activities that the community caries in managing their environment through art. The data are collected trough interview and literatures. The results of this research shows that art can attract the community in Kali Boro riverside to actively participate in the environment improvement and trigger their creativity.
\end{abstract}

Keywords: Kampung, creativity, art.

\begin{abstract}
ABSTRAK
Kampung sebagai penyangga kebudayaan kota memiliki peranan yang penting dalam pembangunan kota. Berbagai gerakan warga untuk mengelola lingkungan kampungnya menjadi suatu dinamika yang menarik. Tulisan ini merupakan studi terhadap kreativitas warga kampung di bantaran kali Boro. Tulisan ini berusaha mengungkap sejauh mana kreativitas warga kampung di bantaran Kali Boro dalam mengelola lingkungan sekitar melalui kegiatan kesenian. Penelitan kualitatif ini mengambil data dari wawancara, observasi dan kajian kepustakaan. Hasil dari penelitian ini menunjukkan bahwa kegiatan kesenian dapat secara efektif menggerakkan warga kampung di bantaran kali Boro untuk aktif berpartisipasi dalam pembangunan kampung dan memacu kreativitas warganya.
\end{abstract}

Kata Kunci: Kampung, kreativitas, seni

\section{PENDAHULUAN}

\section{Latar Belakang}

Satuan - satuan permukiman di kawasan kota yang dianggap sebagai tatanan permukiman tradisional sebelum masuknya perencanaan permukiman mo -dern, di Indonesia disebut dengan kampung. Istilah kampung kota atau disebut kampung digunakan sejak awal abad ke 20 oleh pemerintah Kolonial Belanda melalui program yang disebut kampung verbrecting. Sejak awal pemerintah Kolonial Belanda telah me-misahkan secara tegas antara warga kampung (indlandsche Gemeente) dengan warga priyayi, pamong praja (stads Gemeente). 
Penggunaan istilah kampung kemudian juga dipakai oleh Indonesia dengan Program Perbaikan Kampung atau KIP yang dimulai sejak awal tahun 1960-an (Setiawan, 2010). Kampung merupakan embrio pertumbuhan, oleh karenanya penataan suatu kawasan kota perlu memperhatikan eksistensi kampung sebagai titik tolak penataan. Kampung dapat menjadi sumber peradaban, kreativitas maupun budaya kota. Dengan menggali potensi sosial, ekonomi, budaya dan karakter bermukim di kampung, akan menjadi dasar paradigma baru dalam menata ruang kota yang lebih berkualitas (Nugroho 2009: 1). Data dari Kementerian Perumahan Rakyat (2009) menyebutkan kampung mendominasi peruntukan lahan di kota-kota Indonesia sekitar 70 persen, kampung menjadi tumpuan perumahan $70-85 \%$ penduduk kota. Dengan demikian kampung masih menjadi tumpuhan bermukim sebagian besar warga kota di Indonesia..

Dalam konteks permukiman penduduk di kota, Indonesia memiliki tiga tipe permukiman. Pertama, tipe permukiman yang terencana dengan infrastruktur dan fasilitas yang lengkap dan dapat dijangkau oleh kendaraan bermotor. Tipe kedua, adalah tipe kampung dengan rumah-rumah yang berada di dalamnya, dan pada umumnya tidak dapat dijangkau dengan mobil maupun motor. Tipe kampung ini merupakan tipe permukiman asli/ lama kota-kota di Indonesia. Ketiga, tipe kampung dengan pemukiman kumuh/ pinggiran (squatter) yang berada pada ruang-ruang marjinal kota seperti bantaran sungai atau tanahtanah milik negara, tipe ini disebut sebagai kampung illegal (Nugroho 2009: 211) Kali Boro adalah salah satu sungai kecil yang melintasi wilayah Kota Surakarta. Di sekitar aliran sungai tersebut terdapat kampung-kampung tempat hidup masyarakat yang secara sosial historis tidak dapat melepaskan diri dari kondisi faktualnya sebagai warga yang hidup di pinggir sungai perkotaan; pemukiman yang padat, kesemrawutan lingkungan dan berbagai persoalan lainnya. Pemerintah telah melakukan beberapa upaya pengelola-an lingkungan di Kali Pepe yang lebih populer. Upaya tersebut membuahkan hasil di beberapa titik bantaran Kali Pepe terlihat penataan yang lebih baik bagi warga masyarakat yang hidup di lingkungan tersebut.

Upaya penataan lingkungan tersebut pertama-tama bukanlah mengenai penataan fisik, melainkan penataan pola pikir dan dan upaya menampung berbagai gagasan dan keinginan masyarakat bantaran Kali terhadap lingkungannya sendiri.

Adanya kegiatan tersebut akhirnya mendorong pada suatu pemikiran akan pengembangan kreativitas ma- 
syarakat kampung di Bantaran Kali Boro melalui kegiatan kesenian. Mengingat wilayah seni menyediakan lingkungan dan praktik kepada para pembelajar (masyarakat) untuk terlibat secara aktif dalam pengalaman, proses, dan pengembangan kreatif (Rohidi, 2016: 147).

\section{Metode}

Tulisan ini berusaha mendeskripsikan kreativitas warga di Bantaran Kali Boro khususnya warga kampung Joyoraharjan, Kelurahan Purwodiningratan, Jebres Surakarta. Dengan pendekatan kualitatif deskriptif diharapkan dapat menggambarkan keadaan subjek yang diteliti. Penentuan subyek penelitian ini dilakukan secara purposive, yaitu teknik pengambilan informan dengan pertimbangan tertentu (Sugiyono 2012: 218-219). Pengumpulan data ditempuh dengan wawancara mendalam terhadap remaja karangtaruna dan beberapa warga kampong, observasi terlibat dan penelusuran kajian kepustakaan.

Pengamatan terlibat dilaksanakan dalam berbagai kegiatan yang berkaitan dengan masalah penelitian, seperti: kegiatan karang taruna, PKK, Siskamling, dan kegiatan sadar lingkungan lainnya. Hal ini dilakukan agar dapat diperoleh pemahaman mengenai prosesproses dan tindakan suatu objek yang diteliti (Spradley, 1980: 53-58).

\section{PEMBAHASAN}

Kota Surakarta atau Solo memiliki slogan "Solo the Spirit of Java" sebagai bagian dari narasi identitasnya. Slogan tersebut kemudian berkaitan langsung dengan berbagai kegiatan budaya yang diselenggarakan oleh pemerintah kota. Tak heran jika di Surakarta banyak digelar festival yang kental dengan muatan tradisi Jawa misalnya Solo Batik Carnival, Festival Gethek, Festival Jenang dan yang belum lama diselenggarakan adalah Festival Gamelan (International Gamelan Festival/ IGF).

Meskipun langkah - langkah pemerintah kota sudah dapat dikatakan baik dalam membangun citra kota solo sebagai kota yang merawat spirit budaya Jawa, namun pergerakan kebudayaan yang terjadi di level masyarakat bawah (grassroot) tidak dapat dikesampingkan begitu saja. Justru gerakan di level grassroot seperti yang terjadi di kampung-kampung lebih berpotensi untuk menumbuhkembangkan spirit menjaga dan mengembangkan kebudayaan dengan lebih mandiri dan partisipatif.

\section{Warga kampung Joyoraharjan} sebagai bagian dari warga kota, turut berupaya menjadi bagian dari pilar pembangunan kota. Kesadaran yang tumbuh secara kolektif tersebut berpotensi menular ke kampung-kampung lain dan menimbulkan suatu gerakan yang lebih besar. Hal yang patut untuk 
diamati adalah bagaimana kesadaran tersebut muncul dan bertumbuh di kalangan warga kampung. Dengan segala potensi dan keterbatasannya mereka bergerak untuk membangun lingkungan mereka sendiri untuk mencapai suatu kondisi yang lebih baik. Tanpa terlalu bergantung pada campur tangan pemerintah secara langsung, warga kampung berusaha memetakan sendiri kebutuhan-kebutuhannya dan mencari cara untuk menyelesaikan persoalan-persoalan bersama.

\section{Pengembangan Potensi Kampung Melalui Kegiatan Kesenian}

Kampung Joyoraharjan adalah salah satu kampung yang terletak di bantaran Kali Boro. Kampung ini meliputi tiga RT yaitu RT 01, 02 dan 03 ke-lurahan Purwodiningratan. Kampung ini bersebelahan dengan pasar Ledoksari dan memang sebagian besar warga kampung Joyoraharjan berprofesi sebagai pedagang di pasar tersebut. Kampung tersebut juga tidak jauh dengan salah satu stasiun kereta api yang ada di kota Surakarta yaitu stasiun Jebres. Lingkungan fisik kampung tersusun dari bangunan pemukiman warga yang padat dengan jalur-jalur gang yang menjadi sarana lalu-lalang penduduk setempat.

Ide atau gagasan untuk merubah nuansa kampung yang padat dan kurang menarik menjadi kampung yang lebih bersih dan memiliki daya tarik muncul dari kalangan generasi muda. Para generasi muda atau remaja ter-sebut tergabung dalam karang taruna Anjaya. Atas inistatif mereka perubahan di kampung Joyoraharjan dimulai.

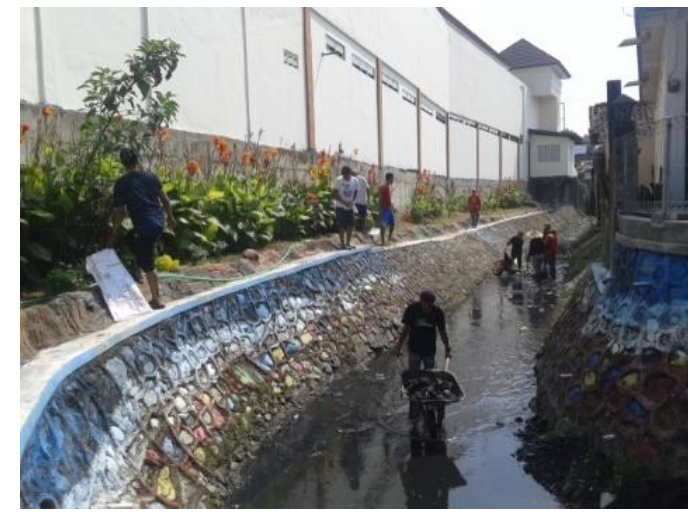

Gambar 1

Kegiatan Rutin Membersihkan Kali Boro (Foto : Endang Sri Handayani, 2018)

Pada mulanya mereka ingin membersihkan lingkungan sepanjang tepian sungai. Bersama-sama mereka melaku-kan pembersihan sampah di lingkungan kampung termasuk membersihkan sungai kecil yang mengalir di kampung tersebut. Kegiatan rutin membersihkan kali Boro terwadahi dalam gerakan kelompok "Kopiko", yang melakukan aktifitas kebersihan kali dan memberi-kan penyuluhan pada warga untuk menjaga kebersihan kali secara rutin,

Namun akhirnya timbul gagasan untuk tidak sekadar membersihkan sungai. Mereka ingin merubah suasana di 
setiap sudut kampung tersebut. Memang secara fisik, tembok-tembok di sepanjang gang kampung mereka sangat potensial untuk dimanfaatkan sebagai media ekspresi.

Gagasan tersebut akhirnya mehasilkan suatu keputusan untuk membuat lukisan mural di sepanjang gang kampung. Namun mereka tidak ingin sekadar membuat mural tanpa suatu konsep yang matang. Mereka ingin membuat mural yang edukatif dan juga memuat nilai-nilai tradisi. Gagasan tersebut mereka kemukaan pada warga lainnya. Pada mulanya ada beberapa warga yang menolak gagasan tersebut. Namun pada akhirnya diperoleh kata sepakat untuk memulai proyek mural kampung tersebut secara bersamasama.

Para remaja kampung menyadari keterbatasan mereka dalam menjalankan proyek tersebut. Untuk itu, dengan bermodal pertemanan dengan remaja dari kampung yang tidak jauh dari kampung Joyoraharjan, mereka berdiskusi tentang beberapa hal yang lebih detail atas proyek mural kampung tersebut. Dari diskusi itulah muncul gagasan untruk membuat mural dengan tema sejarah kampung.

Secara bersama-sama mereka melakukan suatu penelusuran sejarah dengan mewawancarai sejumlah orang di kampung mereka yang dianggap da- pat memberi informasi terkait dengan sejarah kampung mereka. Akhirnya dari proses penelusuran tersebut muncullah nama K.R.H. Kusuma Tanoyo sebagai sosok yang akan dilukiskan dalam mural sejarah kampung. K.R.H Kusuma Tanoyo adalah tokoh yang masih relatif dapat terlacak untuk kepentingan ini. Selain memang jasa tokoh tersebut dianggap penting bagi masyarakat kampung Joyoraharjan.

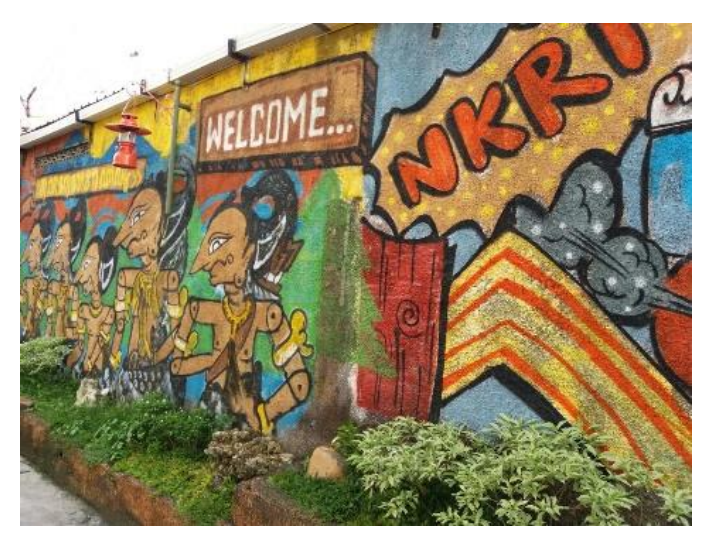

Gambar 2.

$$
\begin{gathered}
\text { Kampung Sepanjang Gang Masuk RT } 2 \\
\text { Kampung Joyoraharjan } \\
\text { (Foto : Endang Sri Handayani, 2018) }
\end{gathered}
$$

Selain menampilkan tokoh, mural sejarah kampung tersebut juga menggambarkan suasana pasar Ledoksari sebagai sebuah pasar tradisional yang telah menjadi bagian dari kehidupan warga kampung Joyoraharjan. Kegiatan ini selain berdampak secara estetik yaitu bertambah keindahan kampung, juga berdampak pada peningkatan kualitas kebersihan kampung. Tembok-tembok dan pagar yang dahulu tampak kusam sekarang menjadi lebih bersih. Kam- 
pung yang nampak suram menjadi lebih hidup dan semarak.Pojok kumuh yang awalnya menjadi tempat kendang ayam di bantaran kali, di ubah menjadi taman dan mural yang estetis.

Kegiatan mural kampung tersebut dapat dilihat sebagai upaya memoles kampung secara fisik agar terlihat lebih indah, melainkan sebagai bagian dari upaya warga kampung untuk menarasikan identitas kolektif mereka yang salah satunya digamit dari penelusuran sejarah lisan. Mereka mencoba melekatkan diri pada sejarah itu untuk mengikat warga dalam suatu ikatan narasi identitas, sekaligus di saat yang sama berupaya mengikatkan diri melalui hubungan sosial yang baru melalui kegiatan bersama.

\section{SIMPULAN}

Kampung sebagai wadah bagi berlangsungnya kehidupan masyarakat bertumbuh seiring dengan kebutuhan warganya. Kampung berkembang dan berdaya karena warganya. Sebagaimana yang telah dilakukan oleh warga kampung Joyoraharjan di bantaran kali Boro. Pemuda sebagai inisiator mencoba membuat suatu gerakan berbasis kesenian untuk menggali potensi warga dan lingkungannya. Kegiatan yang dilakukan secara bersama-sama tersebut mengubah suasana lingkungan kampung sekaligus menopang kebutuhan warga akan edukasi dan pola-pola ko- munikasi baru antar warga. Dalam hal ini pendekatan kesenian merupakan pendekatan yang tepat bagi tercapainya suatu kampung yang mandiri. Optimalisasi kegiatan dan pelibatan berbagai unsur di luar kampung merupakan program yang perlu disusun secara matang ke depan agar potensi warga dan lingkukan kampung Joyoraharjan semakin dapat dikembangkan.

\section{DAFTAR PUSTAKA}

Nugroho, AC. (2009) "Kampung Kota Sebagai Sebuah Titik Tolak Dalam Membentuk Urbanitas dan Ruang Kota Berkelanjutan", Jurnal Rekayasa, Vol.13, No.3, Desember

Rohidi, Tjetjep Rohendi. 2016. Pendidikan Seni: Isu dan Paradigma. Semarang, Cipta Prima Nusantara.

Setiawan, B. 2010.“Kampung Kota dan Kota Kampung: Tantangan Perencanaan Kota di Indonesia". Pidato pengukuhan Jabatan Guru Besar dalam Ilmu Perencanaan Kota UGM, tgl 28 Oktober di Yogyakarta.

Spradley, James P. 2007. Metode Etnografi. Terj. Misbah Zulfa Elizabeth. Yogyakarta: Tiara Wacana

Sugiyono, 2012. Metode Penelitian Kuantitatif, Kualitatif, dan $R \& D$. 